\section{Stress of stoornis?}

Vorige week ben ik verhuisd en verhuizen geeft stress. Verhuizen is zelfs opgenomen als 'life-event' in de officiële stressvragenlijsten. Sterker nog, als je ook nog eens een hypotheek hebt afgesloten heb je zomaar twee life-events te pakken. De stress wordt veroorzaakt doordat de verhuizing in meer of mindere mate om psychische aanpassing vraagt. Life events geven niet alleen stress, ze kunnen ook luxerend zijn voor het ontstaan van psychische stoornissen.

De stress herken ik zeer. Voorafgaand aan de daadwerkelijke verhuizing was er al spanning; vanaf het moment dat we het huis gezien hadden - en we het nog moesten zien te bemachtigen in de huidige, overspannen woningmarkt - tot en met de bouwvergunning die maar op zich liet wachten terwijl de aannemer al klaar stond. En dan nog de verhuizing zelf: te laat begonnen met het opruimen van alle troep uit de veel te grote berging, die we eigenlijk al veel eerder hadden willen uitzoeken, maar waar het uiteraard niet van was gekomen. Dan de paniek, de avond voor de verhuizing, over de grote hoeveelheid spullen die mee moest naar het nieuwe huis zónder berging. En 's ochtends bleek de ijskast nog vol en het balkon niet ontruimd. In de weken na de verhuizing bleef de verwachte euforie over wonen in ons droomhuis uit. Vermoeidheid, de tegelzetters die elke dag om zeven uur al op de stoep stonden, de onuitgepakte dozen (het telkens misgrijpen), een lekkage en al het regel- en papierwerk dat niet ophield stonden 'het grote genieten' nog in de weg. Zolang het bij dit soort stress blijft, spreken we natuurlijk niet van een psychische stoornis. Waar ligt de grens tussen 'normale' stress en een daadwerkelijke aandoening? Dit vragen sommige mensen zich ook af bij de door Arjan Schröder onderzochte stoornis 'misofonie'. Daarbij wekken specifieke geluiden,

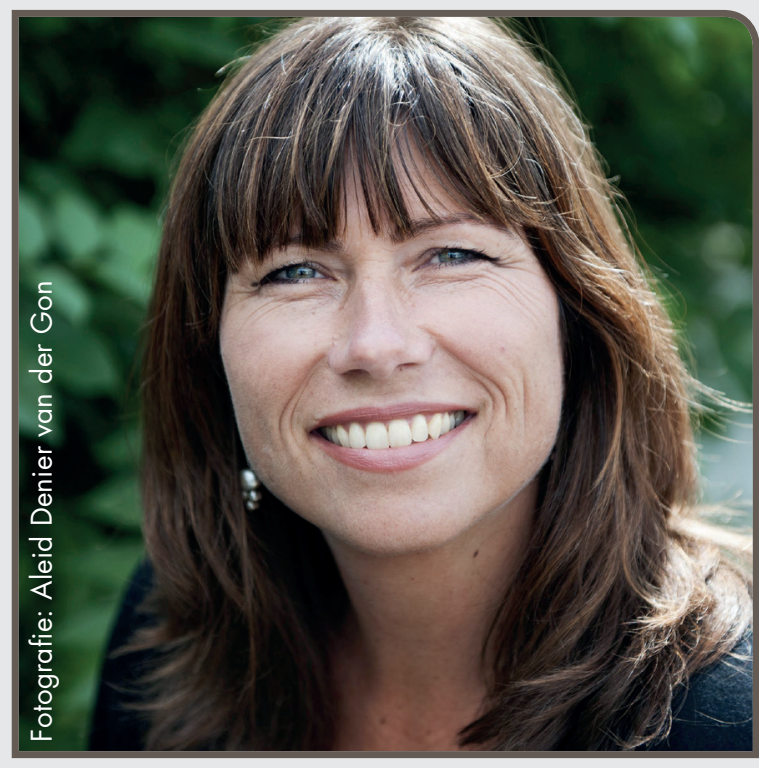

zoals eetgeluiden, extreme gevoelens van woede, walging of haat op (zie de rubriek 'Nieuws'). Zijn dit uitvergrote ergernissen die we allemaal wel kennen, zoals we ons ook kunnen ergeren aan burengeluiden of laag overvliegende vliegtuigen? Of is hier, net als bij alle andere psychische aandoeningen, sprake van een daadwerkelijke stoornis met ernstig psychisch lijden en disfunctioneren? Voor de mensen die er last van hebben, doet deze academische discussie er weinig toe, en zij kunnen hiervoor met succes behandeld worden met CGT. Een andere discussie die binnen de psychiatrie gevoerd wordt, en die van groot belang is voor de autonomie van de patiënt, is die over de wilsbekwaamheid. Gerben Meynen, de recent benoemde, eerste hoogleraar Ethiek en Psychiatrie, wordt hierover geïnterviewd in de rubriek 'In gesprek met'. Hij vraagt zich onder andere af of de in de geneeskunde gebruikte Appelbaum-criteria wel volstaan voor het vaststellen van wilsbekwaamheid bij psychische ziektes als anorexia of ernstige depressies. Met het hanteren van deze criteria is er mogelijk te weinig oog voor de emotionele kant van beslissingen die patiënten nemen en Meynen legt in dit nummer uit waarom hij dat vindt. Mijn verhuisstress ging gelukkig vanzelf weer voorbij. Vanmiddag kwam het nieuwe buurmeisje aangehuppeld: of ze onze hond Saartje weer even mocht aaien, en we aten voor het eerst buiten in de avondzon. Nog wat ontheemd, maar gelukkig in ons nieuwe veelbelovende huis.

Willemijn Scholten, hoofdredacteur 